J. Lake Sci. (湖泊科学), 2016, 28(3): 528-536

DOI 10. 18307/2016. 0308

(c) 2016 by Journal of Lake Sciences

\title{
崇明岛河网浮游植物和无机、有机氮的时空分布特征"
}

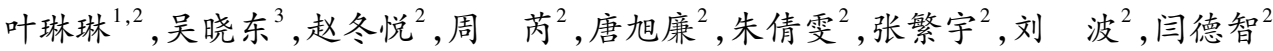 \\ (1: 南通大学地理科学学院, 南通 226000) \\ (2: 华东师范大学, 河口海岸学国家重点实验室,上海 200062) \\ (3: 中国科学院寒区早区环境与工程研究所,冰冻圈科学国家重点实验室,青藏高原冰冻圈观测研究站,兰州 730000)
}

摘 要: 为研究崇明岛河网浮游植物和无机、有机氮的时空分布特征及其相互关系, 于 2014 年 $1 、 4 、 7$ 和 10 月在崇明岛河 网内选取界河、堡镇港、八滧港 3 条河道 9 个采样点采集浮游植物和表层水样, 并选取崇西水闸作为对照点进行研究. 结 果表明: 河网内浮游植物以绿藻和硅藻为主, 其中水闸和堡镇港夏季裸藻生物量所占比例超过 $50 \%$.八澈港总溶解性氮 (TDN) 的主要组分是溶解性无机氮, 而水闸、界河和堡镇港溶解性有机氮 ( DON) 在 TDN 中的比例在夏、秋季低于冬、春 季, 农田土壤释放可能是 DON 的重要来源. 水温、溶解氧和化学需氧量是影响铵态氮浓度变化的重要环境因素. 此外, 通 过冗余分析发现,铵态氮影响绿藻和裸藻分布,尿素影响甲藻分布.

关键词: 崇明岛;浮游植物;无机氮; 有机氮; 时空分布

\section{Temporal and spatial distributions of phytoplankton and inorganic and organic nitrogen in Chongming Island}

YE Linlin ${ }^{1,2}$, WU Xiaodong ${ }^{3}$, ZHAO Dongyue ${ }^{2}$, ZHOU Rui ${ }^{2}$, TANG Xulian ${ }^{2}$, ZHU Qianwen ${ }^{2}$, ZHANG Fanyu $^{2}$, LIU Bo ${ }^{2} \&$ YAN Dezhi $^{2}$

(1: School of Geography Science, Nantong University, Nantong 226000, P.R. China)

(2: State Key Laboratory of Estuarine and Coastal Research, East China Normal University, Shanghai 200062, P.R. China)

(3: Cryosphere Research Station on the Qinghai-Tibetan Plateau, State Key Laboratory of Cryospheric Sciences, Cold and Arid Regions Environmental and Engineering Research Institute, Chinese Academy of Sciences, Lanzhou 730000, P.R.China)

Abstract: To investigate the temporal and spatial distributions of phytoplankton, inorganic and organic nitrogen as well as their relationship, the phytoplankton and surface water samples were collected at nine sites in Rivers Jiehe, Baozhengang, and Bayaogang in Chongming Island in January, April, July and October of 2014, a sample in Chongxi gate site was also collected as control. These results indicated that the phytoplankton community was composed by chlorophyta and bacillariophyta, and the contribution of euglenophyta biomass was more than $50 \%$ in the Chongxi gate and River Baozhengang in summer. Dissolved inorganic nitrogen (DIN) constituted the major fraction of total dissolved nitrogen (TDN), and the percentages of dissolved organic nitrogen ( DON) in TDN in the Chongxi gate, Rivers Jiehe and Baozhengang were lower in summer and autumn than those in winter and spring, the release from agriculture soil may be an important source of DON. The concentration of ammonium nitrogen was affected by water temperature, dissolved oxygen, and chemical oxygen demand. The redundancy analysis suggested that the distribution of Chlorophyta and Euglenophyta was affected by ammonium nitrogen, and the distribution of Pyrrophyta was affected by urea.

Keywords: Chongming Island; phytoplankton; inorganic nitrogen; organic nitrogen; temporal and spatial distributions

氮素是水生生态系统的重要生源要素, 以往关于浮游植物对氮素吸收利用的研究主要集中在溶解性无 机氮( dissolved inorganic nitrogen, DIN) 方面 ${ }^{[1-3]}$. 江源等 ${ }^{[3]}$ 在东江干流研究发现, 夏季蓝藻、绿藻和硅藻细胞 丰度与铵态氮浓度呈显著正相关. 冯露露等 ${ }^{[1]}$ 通过对全太湖 1 年的野外监测数据进行相关分析发现, 微囊

* 国家自然科学基金项目 (41201076, 41001032) 和河口海岸学国家重点实验室开放基金项目 (SKLEC-KF201310)联 合资助. 2015-04-08 收稿;2015-09-17 收修改稿. 叶琳琳( 1981 ), 女, 讲师;E-mail: yelinlin8164@ 163.com. 
藻丰度与硝态氮浓度呈显著负相关, 绿藻、硅藻丰度与硝态氮浓度呈显著正相关. 因此, 不同区域水生生态 系统和浮游植物群落吸收利用的主要氮素形式具有显著差异. 近年来有大量研究表明 ${ }^{[4-6]}$, 浮游植物在生长 过程中会受到氮素限制作用. 对日本富营养化湖泊 Inba 的研究发现 ${ }^{[6]}$, 夏季水体 DIN 浓度迅速降低, 微囊 藻和鱼腥藻生长受到氮限制. 而溶解性有机氮 (DON) 也是水生生态系统中总溶解性氮 ( TDN) 的重要组 分 ${ }^{[7-9]}$, 在以色列 Kinneret 湖研究发现 ${ }^{[8]}, 3$ 月和 9 月 DON 在 TDN 中所占比例分别为 $53 \%$ 和 $89 \%$. 并且 DON 具有一定生物可利用性 ${ }^{[9-10]}$, 可以被浮游植物直接或间接吸收利用, 与某些有害藻华的发生密切相关 ${ }^{[11-12]}$. 通过 ${ }^{15} \mathrm{~N}$ 示踪实验研究发现 ${ }^{[1]}$, 美国加州海岸 DON 中尿素为多边舌甲藻赤潮的形成提供了重要氮源. Dai 等 ${ }^{[12]}$ 通过室内培养实验研究发现, 从滇池分离得到的铜绿微囊藻无菌株能吸收利用 DON 中氨基酸组分维 持自身生长和毒素合成. 综上所述, DON 也是影响浮游植物生长的重要氮素形态, 并且在水体出现氮限制情 况下, 能为浮游植物的生长提供重要氮源补充 ${ }^{[8]}$.

崇明岛位于长江河口,三面环江,一面濒海, 是我国第三大岛. 岛内河网密集, 河道引排受涵闸控制,引 排期河网在潮汐作用下通过开启南沿各水闸将长江水引人; 而非引排期, 各水闸基本处于关闭状态, 将内河 水体与长江隔离, 形成了近乎封闭的水体 ${ }^{[13-14]}$. 有研究表明 ${ }^{[14]}$, 长江口水体氮素污染严重, 长江下游干流水 体中氮素分布特征呈显著空间异质性 ${ }^{[15]}$. 那么在这种引水背景下, 崇明岛河网水体氮素形态的分布特征如 何? 浮游植物对氮素的吸收利用是水生生态系统氮循环的重要环节, 目前关于崇明岛河网不同浮游植物群 落对氮素形态的响应关系还不清楚, 张颖纯等 ${ }^{[14]}$ 探讨了崇明岛河网各种无机氮素与浮游植物的相互作用机 制, 但并没有探讨溶解性有机氮的时空分布特征及其与浮游植物组成的相关性. 因此, 本研究自西向东选取 崇明岛 3 条典型污染河道, 分析了不同季节水质理化参数以及浮游植物群落组成, 明确了无机氮和有机氮 的时空分布特征及影响因子, 并运用穴余分析 (redundancy analysis, RDA) 探讨了浮游植物群落与各氮素形 态的关系,为岛内河网富营养化防治提供重要参考依据.

\section{1 材料和方法}

\section{1 研究区域概况}

崇明岛属沿海平原感潮河网地区,水资源主要来自长江水的供给和降雨形成的地表径流. 根据长江径 流特点, 将 1-4 月归为枯水期, 5-10 月为丰水期. 岛内河网密集, 市级河道南横引河和北横引河为东西走 向, 分别贯通崇明岛南部和北部地区. 31 条县级河道均为南北走向, 河道 $20 \sim 30 \mathrm{~m}$, 水深 $1.5 \sim 3.0 \mathrm{~m}$. 河水南 进北出, 河道南北两侧均有水闸控制河水进出, 阻挡咸潮人侵. 崇明岛南部以居民区和少量工业区为主, 中 部以农业种植区为主, 北部以养殖区和种植区为主 ${ }^{[16]}$.

\section{2 样品采集与分析}

崇明岛河网水质具有明显的空间分异特征. 水 质南部优于北部, 西部优于东部 ${ }^{[17]}$. 因此, 本次研究 自西向东选取崇西水闸、界河、堡镇港和八滧港为研 究对象,其中崇西水闸设置 1 个采样点作为对照, 其 它 3 条河网分别设置 3 个采样点 (图 1). 用 YSI 记录 现场水温 (WT)、溶解氧 (DO) 浓度和 $\mathrm{pH}$ 值水质参数 的变化.

使用采水器采集水样,过滤 $250 \mathrm{ml}$ 水样用于测 定叶绿素 a(Chl.a) 浓度. $1 \mathrm{~L}$ 水样加人 $10 \mathrm{ml}$ 鲁哥试 剂固定,在实验室沉淀浓缩至 $30 \mathrm{ml}$, 在倒置显微镜 (Zeiss Axiovert 135) 下进行鉴定和计数, 浮游植物的 鉴定方法参照《中国淡水藻类: 系统、分类及生 态 $\rangle^{[18]}$. Chl.a 浓度使用乙醇提取分光光度法测定, 总

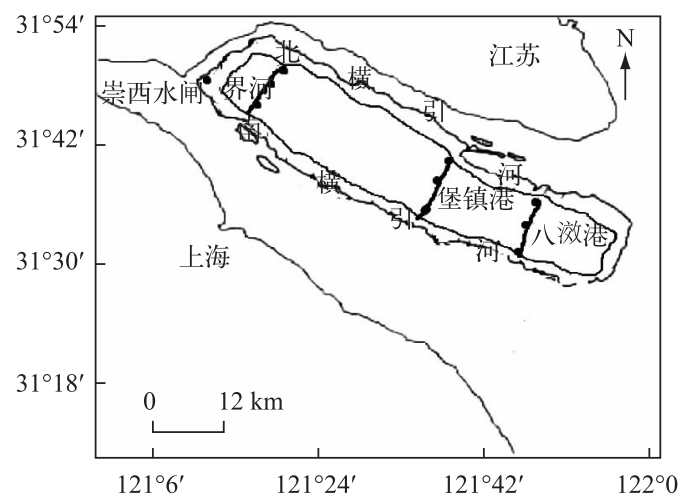

图 1 崇明岛河网采样点位置

Fig. 1 Location of sampling sites in Chongming Island 磷 (TP) 浓度采用钼酸铵分光光度法测定, 总氮 (TN) 和总溶解性氮 (TDN) 浓度采用紫外分光光度法测定, 硝 态氮 $\left(\mathrm{NO}_{3}^{-}-\mathrm{N}\right)$ 浓度采用酚二磺酸分光光度法测定, 铵态氮 $\left(\mathrm{NH}_{4}^{+}-\mathrm{N}\right)$ 浓度采用纳氏试剂分光光度法测定, 亚 
硝酸盐氮 $\left(\mathrm{NO}_{2}^{-}-\mathrm{N}\right)$ 浓度采用重氮偶氮法测定, 化学需氧量采用高锰酸盐指数 $\left(\mathrm{COD}_{\mathrm{Mn}}\right)$ 法测定 ${ }^{[19]}$. 溶解性有 机氮 $[\mathrm{DON}]=[\mathrm{TDN}]-\left[\mathrm{NH}_{4}^{+}-\mathrm{N}\right]-\left[\mathrm{NO}_{3}^{-}-\mathrm{N}\right]-\left[\mathrm{NO}_{2}^{-}-\mathrm{N}\right]$. 尿素 (urea) 浓度采用二乙酰一肜-氨基硫脉分光光度 法测定 ${ }^{[20]}$.

\section{3 数据分析}

本文中数据不满足方差分析的要求, 故采用 Kruskal-Wallis 非参数检验比较不同河道环境因子参数及浮 游植物的差异性. 利用 Canoco 软件对环境因子与浮游植物数据进行分析, 首先对浮游植物数据进行去趋势 对应分析 (detrended correspondence analysis, DCA), DCA 分析结果中的 4 个排序轴的梯度长度最大值大于 3 时才适合进行 CCA 分析,否则适用于基于线性的圥余分析.

\section{2 结果}

\section{1 浮游植物群落组成的时空变化}

水闸浮游植物主要由绿藻、硅藻和裸藻组成, 其中冬、春季硅藻生物量所占比例超过 $95 \%$. 界河浮游植 物主要由绿藻、硅藻、裸藻和隐藻组成, 春季绿藻生物量所占比例达到最大 $(58 \%)$, 夏季裸藻生物量所占比 例达到最大 $(37 \%)$ ). 堡镇港浮游植物主要由绿藻 ( $3 \%$ ～18\%) 和硅藻 ( $15 \% \sim 95 \%)$ 组成, 但夏季裸藻生物量 所占比例达到 $54 \%$.八滧港浮游植物主要由裸藻、绿藻和硅藻组成(图 2).

隐藻 蓝藻 $\mathbb{Z 1 0}$ 甲藻 金藻
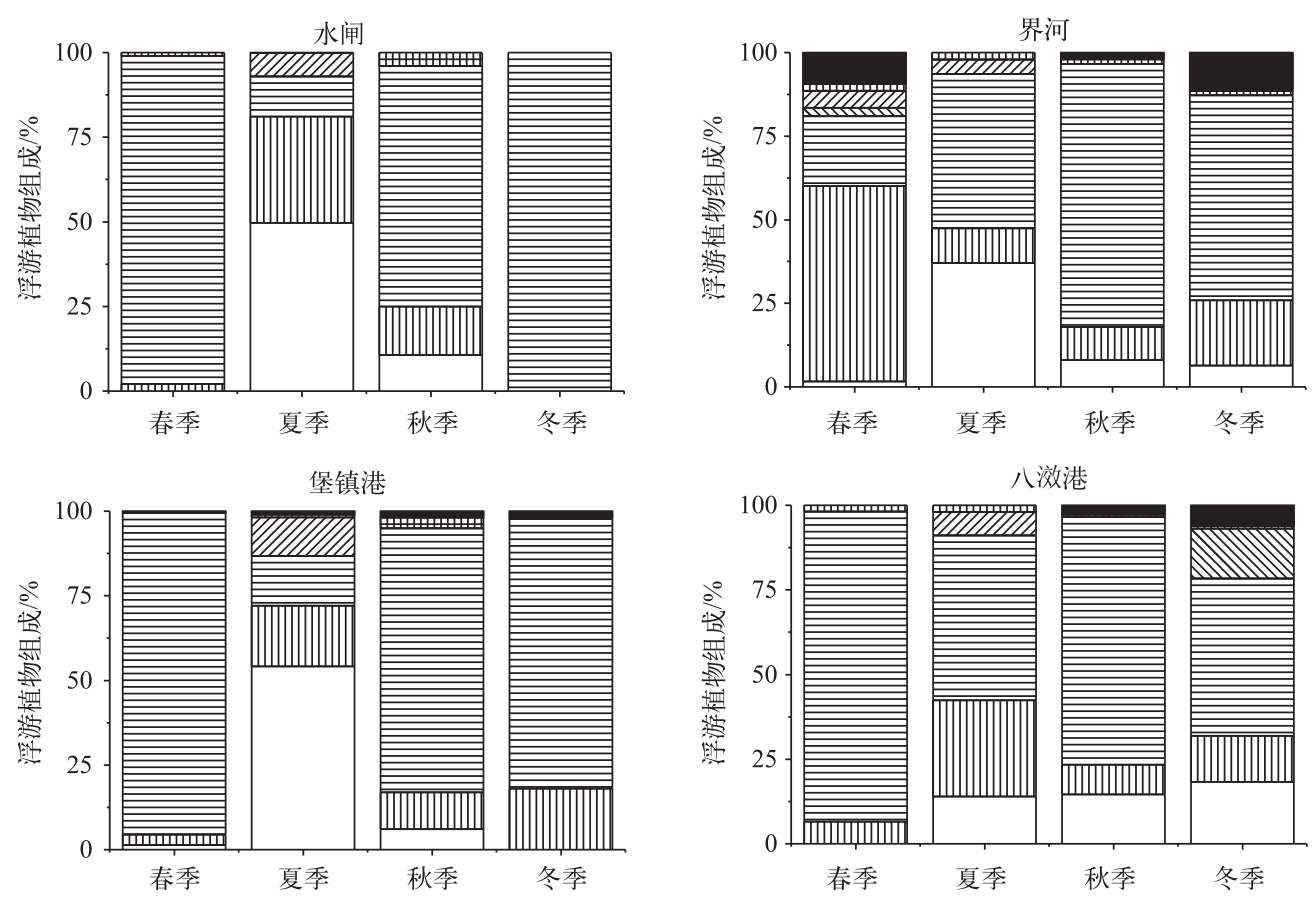

图 2 浮游植物群落组成的时空变化

Fig. 2 Temporal and spatial variations of phytoplankton biomass contribution

\section{2 浮游植物丰度的时空变化}

水闸、界河、堡镇港和八滧港总浮游植物丰度, 绿藻、硅藻、裸藻、隐藻、蓝藻、甲藻和金藻丰度均无显著 差异. 水闸和八滧港浮游植物丰度季节变化规律一致, 从春季开始至夏季出现最大值, 然后逐渐降低, 而界 河浮游植物丰度在春季达到最大值 $(2.0 \pm 3.6) \times 10^{5} \mathrm{cells} / \mathrm{L}$. 水闸、堡镇港和八滧港绿藻丰度都在夏季达到最 大值, 分别为 $1.0 \times 10^{6} 、(3.1 \pm 1.5) \times 10^{5}$ 和 $(2.5 \pm 1.1) \times 10^{5} \mathrm{cells} / \mathrm{L}$. 水闸、界河和八滧港硅藻丰度都在秋季达到 
最大值. 水闸、界河和堡镇港裸藻丰度都在夏季达到最大, 分别为 $5.0 \times 10^{4} 、(2.7 \pm 0.2) \times 10^{4}$ 和 $(4.4 \pm 5.0) \times 10^{4}$ cells $/ \mathrm{L}$. 水闸 4 个季节隐藻丰度均为 0 , 堡镇港冬季隐藻丰度较其它季节有所降低, 水闸和堡镇港蓝藻丰度 都在秋季达到最大值, 分别为 $4.5 \times 10^{5}$ 和 $(2.9 \pm 2.0) \times 10^{5}$, 除界河, 水闸、堡镇港和八滧港甲藻丰度都在夏季 达到最大值 (图 3).
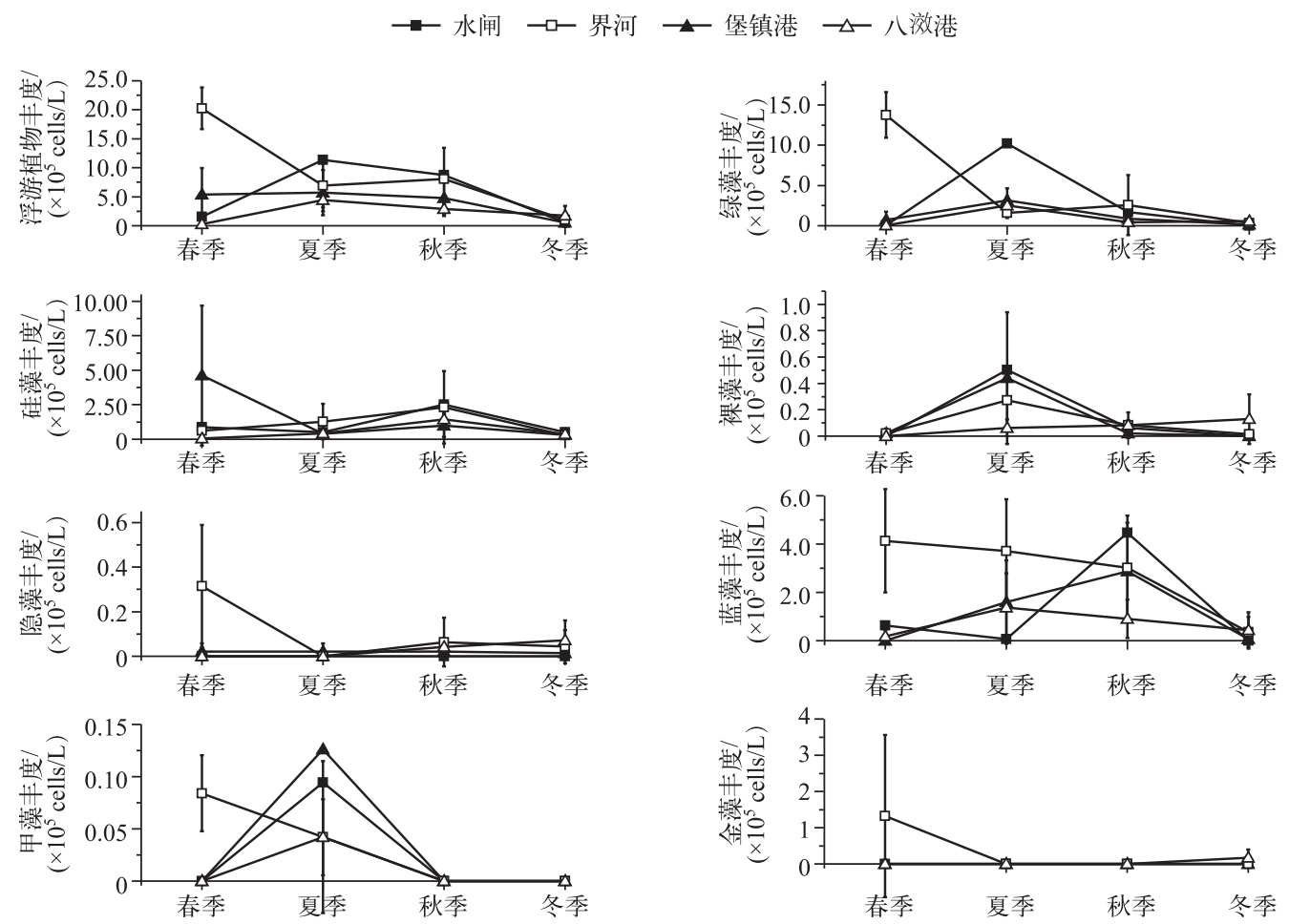

图 3 浮游植物丰度的时空变化

Fig.3 Temporal and spatial variations of phytoplankton abundance

\section{3 水温、 $\mathrm{DO} 、 \mathrm{pH}$ 值、COD $\mathrm{Mn}$ 和 Chl.a 浓度的时空变化}

水闸、界河、堡镇港和八滧港的水温、 $\mathrm{DO} 、 \mathrm{pH}$ 值、 $\mathrm{COD}_{\mathrm{Mn}}$ 和 $\mathrm{Chl} . \mathrm{a}$ 浓度均没有显著差异. 水闸、界河、堡镇 港和八滧港的水温呈明显的季节变化规律, 夏季温度最高, 冬季温度最低. DO 浓度与水温变化规律基本相 反, 夏季最低, 界河和堡镇港春季最高. 岛内河网水体呈碱性, 其中水闸和界河 $\mathrm{pH}$ 值在采样期间逐渐降低, 堡镇港和八滧港秋季降至最低值后, 冬季有所增加. 界河、堡镇港和八滧港的 $\mathrm{COD}_{\mathrm{Mn}}$ 都在夏季达到最大值, 分别为 $5.97 \pm 0.81 、 5.74 \pm 0.77$ 和 $6.67 \pm 0.41 \mathrm{mg} / \mathrm{L}$. 而水闸的 $\mathrm{COD}_{\mathrm{Mn}}$ 在冬季达到最大值. 水闸、界河、堡镇港与 八滧港的 Chl.a 浓度没有显著差异,但水闸与 3 条河流 Chl.a 浓度的季节变化规律不同,水闸的 Chl.a 浓度在 夏季达到最大值, 而 3 条河流的 Chl.a 浓度在春季达到最大值 (图 4).

\section{4 无机氮和有机氮的时空变化}

水闸、界河、堡镇港与八滧港的 $\mathrm{NH}_{4}^{+}-\mathrm{N} 、 \mathrm{NO}_{3}^{-}-\mathrm{N}$ 和 DON 浓度都没有显著差异. 水闸与 3 条河流的 $\mathrm{NH}_{4}^{+}-\mathrm{N}$ 浓度变化规律基本一致, 先增加再减小, 但水闸 $\mathrm{NH}_{4}^{+}-\mathrm{N}$ 浓度在秋季达到最大, 而其它河流均在夏季达到最 大. $\mathrm{NO}_{3}^{-}-\mathrm{N}$ 浓度季节变化存在波动,但水闸与 3 条河流的季节变化基本一致. 水闸的 $\mathrm{NH}_{4}^{+}-\mathrm{N}$ 与 $\mathrm{NO}_{3}^{-}-\mathrm{N}$ 在 DIN 中所占比例的季节变化规律相反, $\mathrm{NH}_{4}^{+}-\mathrm{N}$ 秋季所占比例最高 ( $57 \%$ ), 春季最低 (19.7\%), 而 $\mathrm{NO}_{3}^{-}-\mathrm{N}$ 在春 季所占比例最高 $(80 \%)$, 秋季最低 ( $43 \%$ ), 秋季 $\mathrm{DIN}$ 以 $\mathrm{NH}_{4}^{+}-\mathrm{N}$ 为主, 而其它季节以 $\mathrm{NO}_{3}^{-}-\mathrm{N}$ 为主, $\mathrm{NO}_{3}^{-}-\mathrm{N}$ 在 DIN 中所占比例均超过 $50 \%$. 界河的 $\mathrm{NH}_{4}^{+}-\mathrm{N}$ 与 $\mathrm{NO}_{3}^{-}-\mathrm{N}$ 在 DIN 中所占比例的季节变化规律相反, 夏季 DIN 以 $\mathrm{NH}_{4}^{+}-\mathrm{N}$ 为主, 所占比例为 $68 \% \pm 19 \%$, 其它季节以 $\mathrm{NO}_{3}^{-}-\mathrm{N}$ 为主, 春季所占比例最高, 达到 $80 \% \pm 8 \%$. 堡镇港夏 

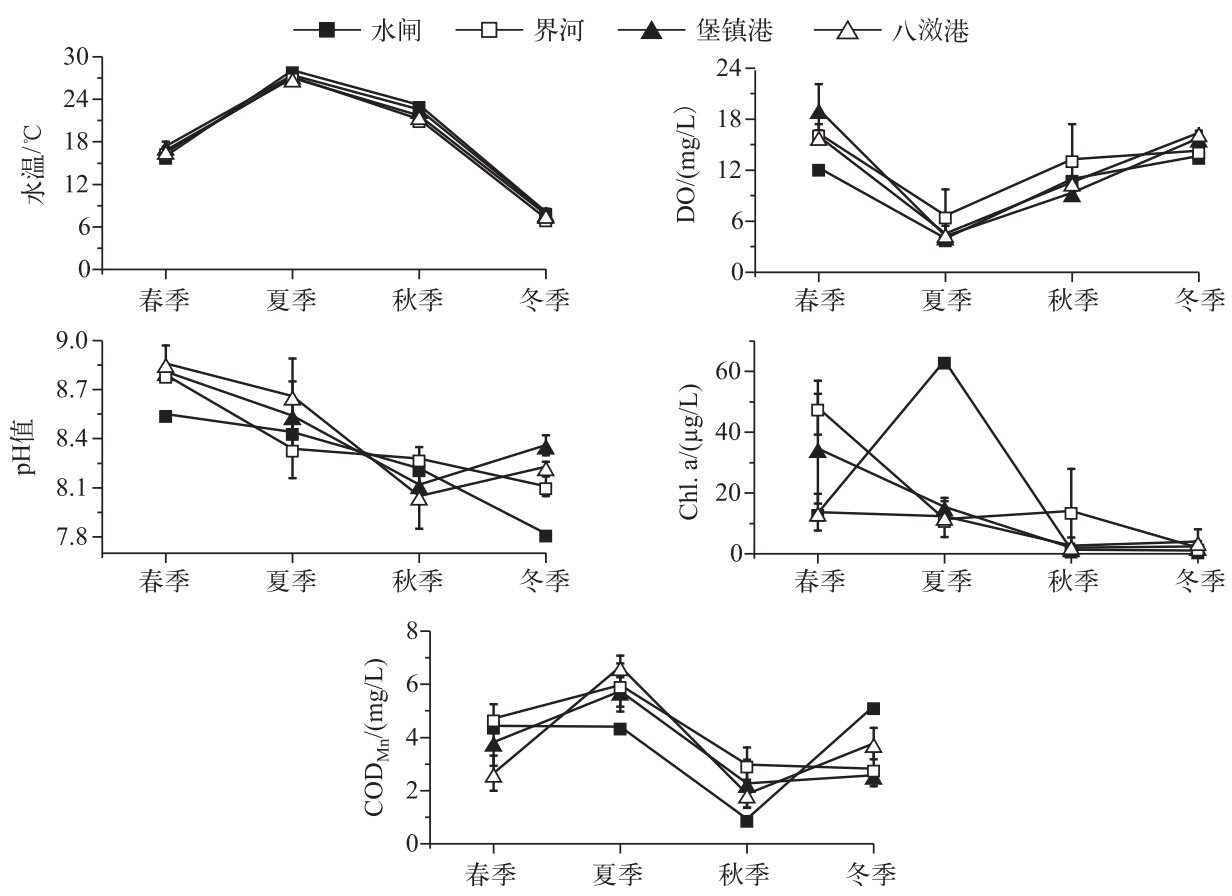

图 4 水温、DO、pH 值、Chl.a 和 $\mathrm{COD}_{\mathrm{Mn}}$ 浓度的时空变化

Fig.4 Temporal and spatial variations of water temperature, DO, $\mathrm{pH}$, Chl.a and $\mathrm{COD}_{\mathrm{Mn}}$ concentrations

季 DIN 以 $\mathrm{NH}_{4}^{+}-\mathrm{N}$ 为主, 所占比例为 $54 \% \pm 10 \%$, 其它季节以 $\mathrm{NO}_{3}^{-}-\mathrm{N}$ 为主, 春季所占比例最高, 达到 $79 \% \pm$ $10 \%$. 八滧港 $\mathrm{DIN}$ 中的主要组分是 $\mathrm{NO}_{3}^{-}-\mathrm{N}$, 春、冬季所占比例高于夏、秋季.

水闸的 DON 浓度变幅为 $0.86 \sim 1.46 \mathrm{mg} / \mathrm{L}$. 界河、堡镇港和八滧港的 DON 浓度变幅分别为 $0.63 \pm 0.11 \sim$ $1.30 \pm 0.16 \mathrm{mg} / \mathrm{L} 、 0.81 \pm 0.17 \sim 1.47 \pm 0.14 \mathrm{mg} / \mathrm{L}$ 和 $0.60 \pm 0.10 \sim 1.12 \pm 0.42 \mathrm{mg} / \mathrm{L}$, 并且都在秋季出现最小值. 水 闸的 DON 在 TDN 中所占比例为 34\% 52\%. 界河、堡镇港和八滧港的 DON 在 TDN 中所占比例分别为 $17 \% \pm$ $6 \% \sim 55 \% \pm 5 \% 、 31 \% \pm 4 \% \sim 53 \% \pm 6 \%$ 和 $26 \% \pm 4 \% \sim 46 \% \pm 11 \%$. 水闸以及 3 条河流的 DON 在 TDN 中所占比例 均为夏、秋季低, 冬、春季高.

水闸、界河、堡镇港与八滧港的尿素浓度没有显著差异. 水闸尿素浓度变幅为 $0.02 \sim 0.15 \mathrm{mg} / \mathrm{L}$, 界河、堡 镇港和八澈港的尿素浓度变幅分别为 $0.006 \pm 0.004 \sim 0.32 \pm 0.15 、 0.005 \pm 0.003 \sim 0.14 \pm 0.013$ 和 $0.01 \pm 0.005 \sim$ $0.37 \pm 0.30 \mathrm{mg} / \mathrm{L}$. 水闸、界河、堡镇港和八滧港的尿素浓度都在夏季达到最大值, 除水闸外, 3 条河流尿素浓 度最低值均出现在春季. 尿素在 DON 中所占比例变幅较大, 其中在界河春季仅占 $0.48 \% \pm 0.28 \%$, 在夏季达 到 $42.82 \% \pm 19.73 \%$. 在堡镇港和八滧港的季节变化规律也是夏季比例最高, 春季比例最低 (图 5).

\section{5 浮游植物和环境因子的 RDA 分析}

DCA 分析结果中 4 个排序轴的梯度长度最大值为 1.779 , 因此使用 RDA 分析. 结果显示前两个轴共解 释了 $36.5 \%$ 的物种数据的方差, $79.5 \%$ 的物种与环境关系的方差累计百分比 (表 1 ).

\section{3 讨论}

\section{1 河网内无机氮的时空变化}

八滧港位于崇明岛东部地区, 水质较差, 该区域主要废水来源为居民生活污水和养殖废水 ${ }^{[17]}$. 有研究 表明 ${ }^{[21]}$, 生活废水和养殖废水的 $\mathrm{NO}_{3}^{-}-\mathrm{N}$ 浓度较低, 但本研究发现, 八滧港 4 个季节水体的 DIN 中主要组分 都是 $\mathrm{NO}_{3}^{-}-\mathrm{N}$, 这与太湖 ${ }^{[1]}$ 和天目湖沙河水库 ${ }^{[22]}$ 水体 $\mathrm{DIN}$ 组分结构一致, 而其它河网 $\mathrm{NH}_{4}^{+}-\mathrm{N}$ 和 $\mathrm{NO}_{3}^{-}-\mathrm{N}$ 所占 比例均有季节性差异,其中界河和堡镇港夏季 $\mathrm{DIN}$ 都是以 $\mathrm{NH}_{4}^{+}-\mathrm{N}$ 为主,其它季节以 $\mathrm{NO}_{3}^{-}-\mathrm{N}$ 为主. 

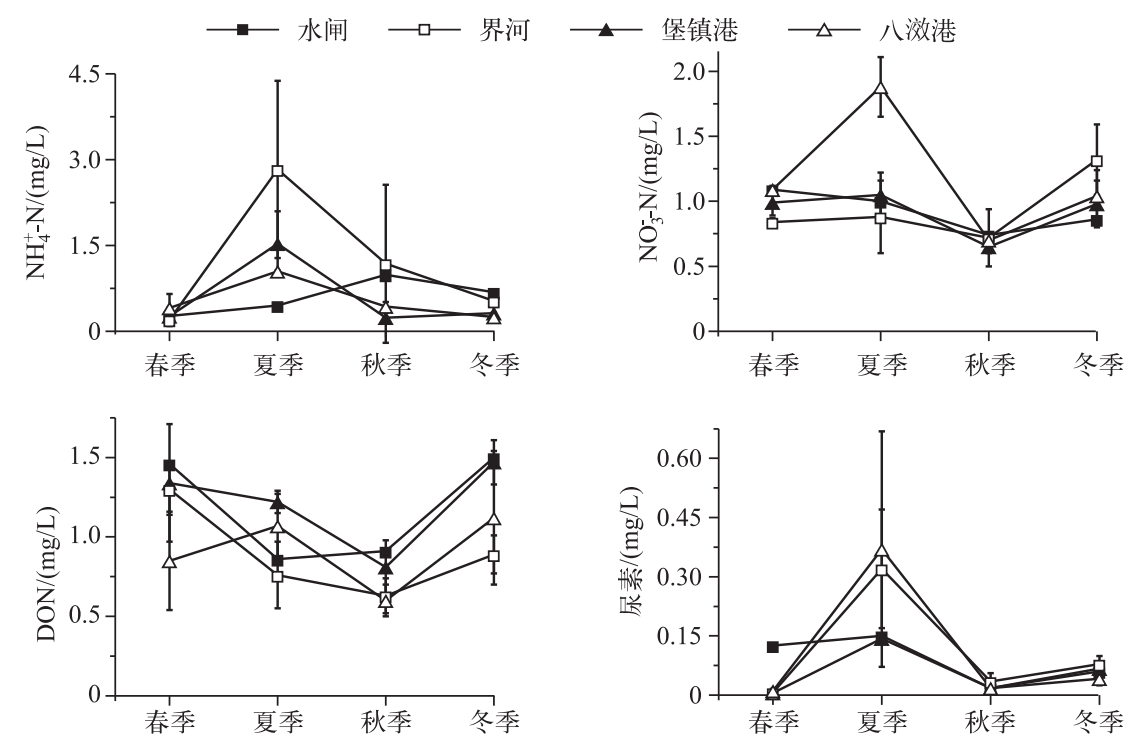

图 $5 \mathrm{NH}_{4}^{+}-\mathrm{N} 、 \mathrm{NO}_{3}^{-}-\mathrm{N} 、 \mathrm{DON}$ 和尿素浓度的时空变化

Fig.5 Temporal and spatial variations of $\mathrm{NH}_{4}^{+}-\mathrm{N}, \mathrm{NO}_{3}^{-}-\mathrm{N}$, DON and urea concentrations

表 1 浮游植物组成与环境因子的 RDA 分析

Tab.1 Results from RDA of phytoplankton communities in relation to environmental factors

\begin{tabular}{lcccc}
\hline & 排序轴 1 & 排序轴 2 & 排序轴 3 & 排序轴 4 \\
\hline 特征值 & 0.282 & 0.084 & 0.056 & 0.022 \\
种类与环境因子相关系数 & 0.830 & 0.703 & 0.585 & 0.379 \\
$\quad$ 累积百分比变化率/\% & & & & 44.4 \\
$\quad$ 物种 & 28.2 & 36.5 & 42.2 & 96.5 \\
$\quad$ 物种-环境相关性 & 61.3 & 79.5 & 91.7 & \\
\hline
\end{tabular}

DO 和水温是影响河道水体中氮素形态和迁移转化的重要因素. 一般来说, 浮游植物产氧会导致水体中 DO 浓度增加, 但本文研究结果表明, DO 浓度与水温呈负相关 (图 6), 这与苏州河 ${ }^{[23]}$ 、崇明岛河网 ${ }^{[14]}$ 水体研 究规律相一致,表明崇明岛河网水体 DO 浓度主要受水温控制而非浮游植物光合作用控制. 此外, $\mathrm{NH}_{4}^{+}-\mathrm{N}$ 浓 度与水温呈正相关 (图 6), 界河和堡镇港夏季 $\mathrm{DIN}$ 以 $\mathrm{NH}_{4}^{+}-\mathrm{N}$ 为主, 这与厦门马軹湾 ${ }^{[24]}$ 、富营养化水库 Caygöre ${ }^{[25]}$ 的研究结果相一致, 在温度较高的季节, 由于有机物的降解和氧化, 如氨化作用的加强 ${ }^{[26]}, \mathrm{NH}_{4}^{+}-\mathrm{N}$ 成为无机氮的主要存在形态. 本研究发现, $\mathrm{NH}_{4}^{+}-\mathrm{N}$ 与 DO 浓度呈负相关 (图 6), 这与 Liangtan 河 ${ }^{[27]}$ 、台湾 Danshui 河 ${ }^{[28]}$ 的研究结果一致. DO 是控制硝化-反硝化反应的重要因子, $\mathrm{NH}_{4}^{+}-\mathrm{N}$ 氧化的发生需要 $\mathrm{DO}$ 的参 与 ${ }^{[29-30]}$. 此外, $\mathrm{NH}_{4}^{+}-\mathrm{N}$ 与 $\mathrm{COD}_{\mathrm{Mn}}$ 浓度呈正相关 (图 6), 这与在平原河网区南通市污染河道的研究规律一 致 ${ }^{[31]}$, 表明生活污水中好氧污染物增加可能伴有 $\mathrm{NH}_{4}^{+}-\mathrm{N}$ 的注人.

\section{2 河网内有机氮的时空变化}

DON 是 TDN 的重要组分, 有研究表明, 在以农业用地为主要土地利用方式的流域内, 河流中 DON 在 TDN 中所占比例达到 $72 \% \sim 97 \%{ }^{[32]}$. 此外, 大量研究 ${ }^{[33-34]}$ 表明, DON 浓度变化具有显著季节规律, 夏季 DIN 浓度降低的过程中 DON 浓度开始显著增加 ${ }^{[35-36]}$. 有研究发现, 濑户内海 2006 年 DON 浓度从春季开始增加, 在夏季达到最大值后开始减少 ${ }^{[33]}$. 此外, 河口水体夏、秋季 DON 在 TDN 中所占比例高于春季和冬季 ${ }^{[37]}$. 但 本文研究发现,岛内河网水体夏、秋季 DON 在 TDN 中所占比例低于春、冬季. 水闸和界河春季 DON 是 TDN 的主要组分, 而夏、秋、冬季 DIN 是 TDN 的主要组分. 堡镇港春季和冬季 DON 在 TDN 中所占比例高于 $50 \%$. 


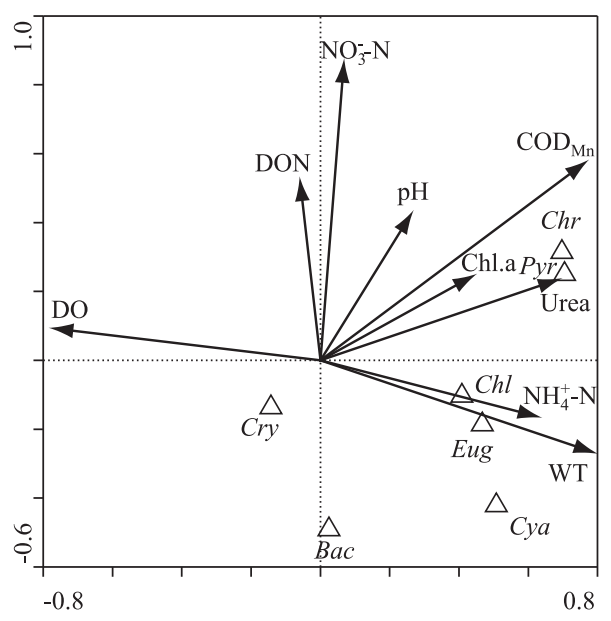

图 6 环境因素与浮游植物的 RDA 排序图 (Cry、Cya、Pyr、Chr、Bac、Chl 和 Eug 分别代表 隐藻、蓝藻、甲藻、金藻、硅藻、绿藻和祼藻)

Fig.6 RDA ordination diagram of the environmental factors and phytoplankton community

但八滧港 4 个季节水体 TDN 的主要组分都是 DIN, 表明 河网与河口 DON 来源及循环机制具有显著差异,河口 中沉积物的释放是水体中 DON 的重要来源 ${ }^{[38]}$. 而崇明 岛农业用地所占比例较大, 农田土壤是释放 DON 的重 要来源 ${ }^{[32]}$, 因此在冬、春季, 即枯水期, DON 浓度及其在 TDN 中所占比例较高.

有研究表明, 尿素浓度受外源输人和内源分解双重 因素影响 ${ }^{[22]}$. 由于农业是崇明岛的主要产业, 因此化肥 的使用会导致河网中尿素浓度升高, 本研究发现, 夏季 丰水期随着地表径流的增大, 河网中尿素浓度均达到峰 值. 此外, 尿素是 DON 中重要的生物可利用性组分, 藻 类的降解和细菌矿化分解等内源释放也是其重要来源. 本研究发现尿素与 $\mathrm{NH}_{4}^{+}-\mathrm{N}$ 和 $\mathrm{NO}_{3}^{-}-\mathrm{N}$ 浓度均呈正相关 (图 6), 这与在太湖水体 ${ }^{[39]}$ 的研究结果一致, 表明尿素 与其它氮素形式之间存在相互转化关系. 此外, 尿素与 DO 浓度呈负相关 (图 6), 与 Bogard 等 ${ }^{[40]}$ 的研究结果一 致, 低氧或缺氧环境有利于细菌对有机物的矿化分解, 还可以影响微生物对尿素的吸收利用及䐂酶对尿素的 催化分解作用.

\section{3 影响浮游植物分布的无机氮和有机氮}

本研究表明崇明岛河网浮游植物以硅藻和绿藻为主, 这与以往的研究结果一致 ${ }^{[14]}$. 藻类对氮源的利用 具有选择性, 与藻类的类型、营养状态以及水环境中氮素的形态和浓度有关. 在汾河中下游研究发现, $\mathrm{NH}_{4}^{+}-\mathrm{N}$ 是影响绿藻、裸藻分布的主要无机氮 ${ }^{[41]}$; 但在崇明岛的研究发现 ${ }^{[14]}, \mathrm{NO}_{3}^{-}-\mathrm{N}$ 是河网中绿藻氮素利用的主要 形式. 本研究发现影响绿藻和裸藻分布的是 $\mathrm{NH}_{4}^{+} \mathrm{N}$ (图 6), 这与冯露露等 ${ }^{[1]}$ 在太湖的研究结果一致. 一般认 为, $\mathrm{NH}_{4}^{+}-\mathrm{N}$ 是浮游植物最喜好的氮形态, 因为与其它形态氮相比, 吸收 $\mathrm{NH}_{4}^{+}$所消耗的能量最少 ${ }^{[42]}$. 综上所 述, 除水温、DO 和 $\mathrm{COD}_{\mathrm{Mn}}$ 是影响崇明岛河网 $\mathrm{NH}_{4}^{+}-\mathrm{N}$ 浓度的重要因素外, 河网中优势群落绿藻和裸藻对 $\mathrm{NH}_{4}^{+}-\mathrm{N}$ 的吸收利用也是不可忽略的重要影响因素.

在海洋赤潮的研究中, 尿素是支持赤潮发生的重要氮素形态. 有研究表明 ${ }^{[43]}$, 甲藻对尿素的有效吸收 利用是维持东海赤潮高发区甲藻赤潮暴发的原因之一. 然而, 尿素对于湖泊、河网等水生生态系统中浮游植 物生长的作用研究较少. 杨柳等 ${ }^{42]}$ 在太湖研究发现, 胥口湾优势群落隐藻对尿素吸收速率较高. 本文研究 发现, 尿素是影响甲藻分布的重要有机氮形态(图 6).

\section{4 参考文献}

[ 1 ] 冯露露, 李正鬼, 周 涛. 太湖浮游植物和各形态无机氮的时空分布特征. 湖泊科学, 2012, 24(5):739-745. DOI $10.18307 / 2012.0515$.

[ 2 ] 戴 红, 陈国斌, 李伏庆. 福建福宁湾无机氮含量的变化特征及其对浮游植物的影响. 台湾海峡, 2006, 25(1): $59-66$.

[ 3 ] 江 源, 王 博, 杨浩春等. 东江干流浮游植物群落结构特征及与水质的关系. 生态环境学报, 2011, 20(11): 1700-1705.

[ 4 ] Moisander PH, Ochiai M, Lincoff A. Nutrient limitation of Microcystis aeruginosa in northern California Klamath River reservoirs. Harmful Algae, 2009, 8: 889-897.

[ 5 ] Xu H, Paerl HW, Qin BQ et al. Nitrogen and phosphorus inputs control phytoplankton growth in eutrophic Lake Taihu, China. Limnology and Oceanography, 2010, 55(1) : 420-432.

[6] Kagami M, Hirose Y, Ogura H. Phosphorus and nitrogen limitation of phytoplankton growth in eutrophic Lake Inba, Japan. Limnology, 2013, 14(1): 51-58. 
[ 7 ] 许 海, 秦伯强, 朱光伟. 太湖不同湖区夏季蓝藻生长的营养盐限制研究. 中国环境科学, 2012, 32(12): 2230-2236.

[ 8 ] Berman T, Bronk DA. Dissolved organic nitrogen: a dynamic participant in aquatic ecosystems. Aquatic Microbial Ecology, 2003, 21 : 379-305.

[ 9 ] Wiegner TN, Seitzinger SP, Glibert PM et al. Bioavailability of dissolved organic nitrogen and carbon from nine rivers in the eastern United States. Aquatic Microbial Ecology, 2006, 43: 277-287.

[10] Bronk DA, See JH, Bradley P et al. DON as a source of bioavailable nitrogen for phytoplankton. Biogeosciences, 2007,4 : 283-296.

[11] Kudela RM, Cochlan WP. Nitrogen and carbon uptake kinetics and the influence of irradiance for a red tide bloom off southern California. Aquatic Microbial Ecology, 2000, 21:31-47.

[12] Dai R, Liu H, Qu J et al. Effects of amino acids on microcystin production of the Microcystis aeruginosa. Journal of Hazardous Material, 2009, 161(2/3):730-736.

[13] 应荣弟, 徐 华. 崇明岛水系改造对水资源的影响初探. 上海建设科技, 2004, 4: 10-12.

[14] 张颖纯, 姜德刚, 李建华. 崇明岛"闸控型" 河网水体富营养化特征及其影响因素. 湖泊科学, 2013, 25(3): 366372. DOI 10.18307/2013.0309.

[15] 刘 敏, 林 莉, 董 否等. 长江下游干流水体中氮的空间分布特征. 长江科学院院报, 2015, 32(6): 65-69.

[16] 乐 观. 崇明岛河道水质理化指标及其与三种主要浮游动物分布的相关性研究 [学位论文]. 上海: 华东师范大 学, 2008.

[17］朱英杰, 李建华, 姜德刚. 崇明河网水质污染的空间差异分析. 安徽农业科学, 2010, 38(22): 11906-11912.

[18] 胡鸿钧, 魏印心. 中国淡水藻类: 系统、分类及生态. 北京: 科学出版社, 2006: 100.

[19] 陈伟民, 黄祥飞, 周万平. 湖泊生态系统观测方法. 北京: 中国环境科学出版社, 2005: 122.

[20] Revilla M, Alexander J, Glibert PM. Urea analysis in coastal waters: comparison of enzymatic and direct methods. Limnology and Oceanography: Methods, 2005, 3(7) : 290-299.

[21] 叶宏萌, 袁旭音, 孙西艳等. 太湖北部河网水体营养元素和形态氮研究. 环境科学与技术, 2009, 32(12) : 52-55.

[22] 韩晓霞, 朱广伟, 李兆富等. 天目湖沙河水库尿素含量及其时空分布特征分析. 环境化学, 2015, 34(2) : 377-383.

[23] 刘冬燕, 宋永昌, 陈德辉. 苏州河叶绿素 a 动态特征及其与环境因子的关联分析. 上海环境科学, 2003, 22(4) : 261-264.

[24] 张晓萍. 厦门马金湾水域无机氮的化学特征. 台湾海峡, 2001, 20(3)：319-322.

[25] Celik K. The relationships between chlorophyll-a dynamics, certain physical and chemical variables in the temperature eutrophic Caygören reservoir, Turkey. Iranian Journal of Fisheries Science, 2013, 12(4) : 770-782.

[26] Liikanen A, Martikainen PJ. Effect of ammonium and oxygen on methane and nitrous oxide fluxes across sediment-water interface in a eutrophic lake. Chemosphere, 2003, 52(8): 1287-1293.

[27] Gong D, Gao X, Ntakirutimana T et al. Water quality status along the Liangtan River and control planning alternatives for pollution reduction. Polish Journal of Environmental Studies, 2013, 22(4) : 1061-1067.

[28 ] Lee TY, Shih YT, Hang JC et al. Speciation and dynamics of dissolved inorganic nitrogen export in the Danshui River, Taiwan. Biogeosciences, 2014, 11: 5307-5321.

[29] Ruiz G, Jeison D, Rubilar O et al. Nitrification-denitrification via nitrite accumulation for nitrogen removal from wastewaters. Bioresource Technology, 2006, 97(2) :330-335.

[30] Yang H, Shen Z, Zhang J et al. Water quality characteristics along the course of the Huangpu River (China). Journal of Environmental Sciences, 2007, 19(10): 1193-1198.

[31] 刘 波, 盛 明, 朱 强等.基于水资源调度的平原河网区城市河道氮迁移转化研究. 环境科学, 2014, 35(9): 3373-3380.

[32] Lorite-Herrera M, Hiscock K, Jiménez-Espinosa R. Distribution of dissolved inorganic and organic nitrogen in river water and groundwater in an agriculturally-dominated catchment, south-east Spain. Water, Air, and Soil Pollution, 2009,198 $(1 / 2 / 3 / 4): 335-346$.

[33] Suksomjit M, Nagao S, Ichimi K et al. Variation of dissolved organic matter and fluorescence characteristics before, during and after phytoplankton bloom. Journal of Oceanography, 2009, 65(6): 835-846.

[34] Huo S, Yu H, Xi B et al. Characteristics of dissolved organic nitrogen (DON) in the surface water of Beijing Olympic For- 
est Park. Environmental Earth Sciences, 2014, 71(9) : 4021-4028.

[35] Cartaxana P, Cacador I, Vale C. Seasonal variation of inorganic nitrogen and net mineralization in a salt marsh ecosystem. Mangroves and Salt Marshes, 1999, 3(2): 127-134.

[36] Shammon TM, Hartnoll RG. The winter and summer partitioning of dissolved nitrogen and phosphorus observations across the Irish Sea during 1997 and 1998. Hydrobiologia, 2002, 475(1) : 173-184.

[37] Badr E-S A, Tappin AD, Achterberg EP. Distributions and seasonal variability of dissolved organic nitrogen in two estuaries in SW England. Marine Chemistry, 2008, 110(3/4) :153-164.

[38] Burdige DJ, Zheng S. The biogeochemical cycling of dissolved organic nitrogen in estuarine sediments. Limnology and Oceanography, 1998, 43(8): 1796-1813.

[39］韩晓霞, 朱光伟, 许 海等. 太湖夏季水体中尿素的来源解析. 环境科学, 2014, 35(7) : 2547-2556.

[40] Bogard MJ, Donald DB, Finlay K et al. Distribution and regulation of urea in lakes of central North America. Freshwater Biology, 2012, 57(6) : 1277-1292.

[41] 王爱爱, 冯 佳, 谢树莲. 汾河中下游浮游藻类群落特征及水质分析. 环境科学, 2014, 35(3):915-923.

[42] 杨 柳, 章 铭, 刘正文. 太湖春季浮游植物群落对不同形态氮的吸收. 湖泊科学, 2011, 23 (4) : 605-611. DOI 10.18307/2011.0417.

[43] 苏 莹, 姜聪聪, 石晓勇等. 春季东海赤潮高发区尿素的断面分布及影响因素. 海洋环境科学, 2015, 34(2): 171-175. 